\title{
The Year's Work in Marlowe Studies: 2020
}

\author{
JENNIFER LODINE-CHAFFEY \\ SOUTHEASTERN OKLAHOMA STATE UNIVERSITY
}

Despite the global pandemic, 2020 proved a productive year for Marlowe scholars. Publications included David McInnes' timely edited collection, Tamburlaine: A Critical Reader, Kit Heyam's thought-provoking monograph, The Reputation of Edward II, 1305-1697, Lisa Hopkins' sustained engagement with Marlowe's work in Greeks and Trojans on the Early Modern English Stage, and a significant number of articles and book chapters devoted to the Marlovian corpus. Four current trends, in particular, strike me as noteworthy. First, a number of works attest to the continued interest in exploring Marlowe's dramas using computer algorithms. Second, many scholars assessed early modern publication practices as they relate to Marlowe's works. Third, critics examined how Marlowe incorporated racial and sexual others in his plays, and finally, quite a few pieces investigated the ways that Marlowe's poetry and plays adapted past literary works and influenced the composition of not only literary texts, but also aided in contemporary cultural understandings of history, science, and early modern colonial projects. Studies of Tamburlaine dominated scholarship this past year, although a few scholars considered Marlowe's treatment of religion in Doctor Faustus and a significant number of articles and book chapters assessed Marlowe's engagement with classical Greek and Latin works.

\section{Tamburlaine}

The David McInnes edited collection, Tamburlaine: A Critical Reader, offers an in-depth introduction to the plays, including surveys of the publication, stage, and critical history; an overview of current trends in academic thinking about the works; critical essays that suggest new directions for study; an essay containing resources and ideas about how to teach the texts; and an extensive bibliography. ${ }^{1}$ McInnes's introduction sets out the importance of Tamburlaine plays, which not only "cast $[\ldots]$ a long shadow over the plays written in imitation throughout the

\footnotetext{
The author wishes to thank Darryl Rainbolt, the Interlibrary Loan Specialist at Southeastern Oklahoma State University, who spent many hours gathering books and articles to facilitate this study.

${ }^{1}$ David McInnes, ed. Tamburlaine: A Critical Reader (London: Bloomsbury, 2020).
} 
following decade," but also "have become etched into the popular imaginary." ${ }^{2}$ Noting that reading or watching Marlowe's Tamburlaine plays today is always mediated by Richard Jones' original publication of the work as well as the plays' prologues, McInnes contextualizes the plays, providing readers with a sense of the subversive nature and importance of the works. Staged by the Admiral's Men, Tamburlaine, with its focus on foreign history and its "moral ambivalence," contrasted sharply with the providential and decidedly English history plays put on by the Queen's Company. ${ }^{3}$ Despite their moral ambiguity, the Tamburlaine plays, McInnes suggests, greatly influenced contemporary playwrights, who adopted more psychologically nuanced characters, began to use the five-act structure, and increasingly wrote sequels to successful dramas. In our modern era, renewed interest in Marlowe's Scythian shepherd turned conquering emperor has inspired critics and directors alike. McInnes speculates that the modern fascination with the plays stems from twentieth and twenty-first century experiences with religious radicalism, threats of terrorism, the impact of colonialism, and constructions of masculinity.

In addition to McInnes' introduction, the book's eight essays provide justification for the renewed interest in and importance of Marlowe's Tamburlaine plays. The first three chapters offer an overview of critical reception, theatre history, and current scholarly trends. M. L. Stapleton's essay, "The Critical Backstory: Tamburlaine, 1587-2000—A Reception History," sets the stage by noting the influence of the plays throughout the seventeenth century, "given the number of allusions" found in a variety of texts. ${ }^{4}$ Although Tamburlaine remained influential, its reception throughout the centuries, Stapleton notes, was often ambivalent, with many scholars criticizing its violence and questioning its moral purpose but praising Marlowe's attention to character and style. Similar issues have impacted the staging of the plays, which Peter Kirwan explores in the second chapter. Although recent decades have witnessed a resurgence in performances of the play, Kirwan reminds us that modern critics simultaneously dread and look forward to new stagings of Tamburlaine. Logistical issues challenge directors who must decide whether to stage both plays and which scenes to cut if they opt to decide to include 2 Tamburlaine. Kirwan also provides an overview of some of the most memorable productions of

\footnotetext{
${ }^{2}$ David McInnes, "Introduction," in Tamburlaine: A Critical Reader, 1, 15

${ }^{3}$ McInnes, 5.

${ }^{4}$ M. L. Stapleton, "The Critical Backstory: Tamburlaine, 1587-2000-A Reception History," in Tamburlaine: A Critical Reader, 20.
} 
the play, noting that depictions of the title character vary considerably, because Tamburlaine is portrayed as "sometimes a righteous defender of wrongs, sometimes a tyrant, sometimes a cannibal." $" 5$

Sarah Wall-Randell's “The State of the Art: The Critical Landscape 2000-Present” provides an overview of current critical readings of the plays. She notes that scholarly attention to Tamburlaine "is clearly on the rise," which is supported by the range of critical attention to the Tamburlaine plays in 2020 alone. ${ }^{6}$ Wall-Randell surveys many different critical modes and how scholars are using these lenses to analyze the Tamburlaine plays, including ecocritism, AngloOttoman studies, religious approaches, theater and book history, and Marlowe's debt to the literary past. Critical race studies, in particular, offers important new insights into Tamburlaine and will, Wall-Randell suggests, continue to provide scholars with new understandings concerning how early modern Europeans viewed Middle Eastern religions and people. She also notes that textual scholarship over the last twenty-five years has grown considerably, and now includes looking at paratexts, reevaluating early editions of Marlowe's works, investigating theater history, and focusing on Marlowe's probable collaborative writing.

The next section of Tamburlaine: A Critical Reader provides a selection of essays devoted to new avenues of research. In her chapter, "New Directions: Mending Tamburlaine," Claire M. L. Bourne examines a 1606 copy of Tamburlaine. Bourne reads the textual marginalia to see how the original audience might have interpreted the work, contending that the reader "was interested in the play's exploration of faulty behaviour" and in the tragical dimensions of the play. ${ }^{7}$ Although noting that studies of early copies are fraught with ambiguities, Bourne urges scholars to embrace the uncertainty of reading these traces of readerly presence in early copies of Marlowe's plays. In his chapter, Tom Rutter takes a different approach, investigating how Tamburlaine engages with early modern scientific studies. Throughout the play, Marlowe employs meteorological imagery, which Rutter argues not only symbolizes Tamburlaine's power, but could have been read by the original audiences as signifying either a divine message or natural phenomena. Rutter suggests that Marlowe's religious scepticism is evident in the play,

\footnotetext{
${ }^{5}$ Peter Kirwan, "The Performance History: 'High Astounding Terms'—Tamburlaine and Tamburlaine on Stage," in Tamburlaine: A Critical Reader, 65.

${ }^{6}$ Sarah Wall-Randell, "The State of the Art: The Critical Landscape, 2000-Present," in Tamburlaine: A Critical Reader, 67.

${ }^{7}$ Claire M. L. Bourne, "New Directions: Mending Tamburlaine,” in Tamburlaine: A Critical Reader, 104.
} 
for, by creating a character who uses meteorological signs to influence his followers, the playwright subverts contemporary religious belief and parodies understandings of the divine. ${ }^{8}$

Both Sydnee Wagner and Matthew Dimmock approach Tamburlaine through the lens of critical race studies. Wagner's "Towards a Racialized Tamburlaine" looks at the treatment of race within the plays, arguing that scholars need to acknowledge the nationalist and supremacist project of racial identity inherent in Marlowe's work. Tamburlaine the character, she contends, emphasizes racial differences that go beyond just skin colour, but include also "language, occupation, place of origin, culture, and clothing." These material differences, Wagner suggests, connect Tamburlaine to a range of racial others and reveal the racist rhetoric used in literary representations of non-Europeans. In "Retooling Timür," Dimmock discusses the Scythian origins of Tamburlaine that align him with otherness. Analyzing the historical person that was the basis of Tamburlaine, Dimmock finds traces of Amir Timür Gurgan in Marlowe's play. He argues that Marlowe selected Timür as a subject for his play "because that particular biographical narrative enabled Marlowe to respond to, and engage with, a fundamentally changed world" and visualize the connections between east and west. ${ }^{10}$

The final chapter attends to teaching the Tamburlaine plays. Liam E. Semler divides his essay up into three separate sections, each named for one of Tamburlaine's tents. The white tent section provides an overview of source materials, including a discussion of scholarly Marlowe biographies, an assessment of different editions of the plays, and an inventory of outside readings to assist students. In the red tent segment, Semler offers helpful strategies for teaching the texts, and in the concluding black tent portion, he provides an overview of current critical conversations and lists where instructors and students can locate resources. Each of the three sections provides a useful bibliography to assist those looking for new ways to use Marlowe's play in the college classroom. ${ }^{11}$

Marlowe's Tamburlaine plays inspired a wealth of critical attention not only in McInnes's edited collection, but also in a wide range of scholarly articles and book chapters. Maurice Hunt explored friendship in Tamburlaine, focusing both on how the title character built

\footnotetext{
${ }^{8}$ Tom Rutter, "New Directions: Tamburlaine the Weather Man," in Tamburlaine: A Critical Reader, 107-28.

${ }^{9}$ Sydnee Wagner, "New Directions: Towards a Racialized Tamburlaine," in Tamburlaine: A Critical Reader, 145.

${ }^{10}$ Matthew Dimmock, "New Directions: Retooling Timür," in Tamburlaine: A Critical Reader, 164.

${ }^{11}$ Liam E. Semler, "Three Tents for Tamburlaine: Resources and Approaches for Teaching the Play," in Tamburlaine: A Critical Reader, 167-92.
} 
political alliances and bonds with other characters in 1 Tamburlaine and how Tamburlaine claims friendship with deities in 2 Tamburlaine. ${ }^{12}$ In the first play, Marlowe employs two myths - the ideal love of Damon and Pythias and the violent bond between Pylades and Orestes - that relate to Tamburlaine's relationships with Theridamas and his other allies. Hunt argues that while Tamburlaine first "woos Theridamas in the language of loving friendship," his friendship with his other followers eventually resembles that of Pylades and Orestes. ${ }^{13}$ Of greater interest to Hunt, though, is the phrase "friend of God" from 2 Tamburlaine, which the author reads as a key to understanding Tamburlaine's character. By the end of the play, Tamburlaine stops referencing the Christian God, Allah, or Mahomet, turning instead to Jupiter. Ultimately, Hunt suggests, "the wronged Allah of Mahomet" fulfils the prayers of the faithful Muslims and allows the death of Tamburlaine, who has "lost the divine friendship that matters most."14 Carla Baricz examines the reasons that Richard Jones published the two Tamburlaine plays as a single piece as well as the changes he made to the scripts. ${ }^{15}$ Originally performed separately in 1587, the plays were published together by Jones in 1590, which Baricz argues ignored the performance history of the plays. Jones also cut parts of the play, altered the genre, and added material as a marketing strategy. Scholars today typically treat the plays as one single continuous narrative rather than two separate pieces, even though "the printed versions of the plays on which scholars base claims . . . are not Marlowe's work at all, and one cannot ascribe any kind of authorial intention to them." ${ }^{16}$ Jones's strategies were successful and Baricz speculates that his editorial and publishing decisions may have ensured Marlowe's success as a playwright. However, scholars need to remember that "it is Jones's Tamburlaine that one analyzes whenever one speaks and writes about Marlowe's authorial choices." 17

In addition to her chapter in McInnes' edited collection, Claire Bourne, in her larger study of typography, or the ways that printers and publishers used scene divisions, printed symbols, and woodcuts to represent staged dramas, attends to Richard Jones's first printed

\footnotetext{
12 Maurice Hunt, "Friendship in Marlowe's Tamburlaine the Great," Medieval and Renaissance Drama in England 33 (2020): 118-43.

${ }^{13}$ Hunt, 120.

${ }^{14}$ Hunt, 137.

${ }^{15}$ Carla Baricz, "Richard Jones's Tamburlaine the Great, or How to Print an Early Modern Play and Sequel," Sixteenth Century Journal 51, no. 1 (2020): 29-53.

${ }^{16}$ Baricz, 30.

${ }^{17}$ Baricz, 53.
} 
edition of the Tamburlaine plays. ${ }^{18}$ Reading the text with an eye to the scene divisions and probable omissions of some of Marlowe's original language, Bourne asks if a printed play could effectively represent the movements of the players on and off the stage while offering readers a cohesive and understandable narrative. Jones, Bourne finds, altered the play by omitting the comic bits hinted at in the play's introductory language and through his use of scene divisions. Looking closely at scenes depicting battles in 1 Tamburlaine reveals Jones's attempts to provide the plays with a narrative structure that highlighted Tamburlaine's progress and framed the plays as "Historie." In short, Bourne argues that "Jones's manipulation of scene divisions to repackage the play for readers was [...] informed by his sensitivity to the effects of the play's dramaturgy." ${ }^{19}$ By intervening, Jones created "a heavily mediated text," but one that tried to provide readers with access to the elements of the play that theatre audiences had found thrilling. ${ }^{20}$

Two critics focused on the violence inherent to the Tamburlaine plays. Christopher McKeen argues that Marlowe understood and challenged the violent underpinnings of blank verse, which, in sixteenth century England, paid homage to the imperial and bloody narratives of ancient Greece and Rome. ${ }^{21}$ In 1 Tamburlaine, Marlowe "uses this literary history to resist historiographic narratives of England's imperial destiny."22 McKeen suggests that by having the title character, who is of low birth and violent proclivities, speak in unrhymed English verse, Marlowe effectively created a new literary tradition of blank verse that resists the imperial teleology common in his predecessors. Tamburlaine's speeches are lyrical passages that serve not just to halt the action of the play, but also to "dwell on anticipated or imagined or debated action," loss, and imperial politics. ${ }^{23}$ The form of blank verse used in the Tamburlaine plays, therefore, reveals "the barbaric violence underlying the Roman eloquence and civilization admired by proponents of verse reform." ${ }^{24}$ Jeanette Nguyen Tran also considers the narrative

\footnotetext{
${ }^{18}$ Bourne also briefly assesses the use of the cross marker in published editions of The Jew of Malta and notes the inclusion of a woodcut in the fourth edition of Doctor Faustus. See Claire M. L. Bourne, Typographies of Performance in Early Modern England (Oxford: Oxford University Press, 2020), 115-122, 206-207.

19 Bourne, 163.

20 Bourne, 164.

${ }^{21}$ Christopher McKeen, "Christopher Marlowe, Literary History, and the Lyrical Style of Blank Verse," English Literary Renaissance 50, no. 2 (2020): 173-203.

${ }_{22}^{2}$ McKeen, 174.

${ }^{23}$ McKeen, 175.

${ }^{24}$ McKeen, 179.
} 
possibilities of violence in 1 Tamburlaine. ${ }^{25}$ For Tran, the play's bloody spectacles are not simply celebrations of terrorism, but instead function as the means by which Tamburlaine gains "political visibility." 26 Indeed, misrecognition of Tamburlaine's authority and identity as conqueror "repeatedly engenders spectacular violence." ${ }^{27}$ Such violence, though, according to Tran, should not be interpreted as brutal; instead, "what looks like a barbaric act of indiscriminate physical violence proves to be a measured and appropriate response to a recurring problem: Tamburlaine's inability to achieve recognition." ${ }^{28}$

Matthew Dimmock, whose scholarship also appeared in McInnes' edited collection, extended his study on Marlowe and race with an article entitled "Tudor Turks: Ottomans Speaking English in Early Modern Sultansbriefe." 29 In this piece, Dimmock points out that although many scholars identify Bajazeth as the first theatrical Turkish voice heard in early modern English literature, Marlowe actually uses a trope with a long history. Tracing the history of the Turkish voice in sixteenth century texts, Dimmock finds that Marlowe drew "on an extensive Germano-Italian Sultansbrief in which the sultan's voice is ventriloquized in a series of letters to Christian princes and to the Pope." ${ }^{30}$ The Ottoman voice represented in these texts typically used grandiose language and affirmed violence and was later mimicked and satirized in early modern writings. The letters Dimmock analyses and the connections between these texts and Marlowe's play reveal their "lasting influence in other, more immediate ways, shaping the character and sound of the 'Eastern' tyrant on the early modern English stage." 31

Jeffrey McCambridge explores depictions of Muslims in Tamburlaine, looking at how these plays both use and satirize medieval European literary representations of Islamic peoples and beliefs. Examining a range of literary sources that pre-date Marlowe, McCambridge finds that "Saracens were presented in literature as hostile hordes that formed a diverse-yet unified

\footnotetext{
${ }^{25}$ Jeanette Nguyen Tran, “'Or Else Were this a Savage Spectacle': the Narrative Possibilities of Spectacle in $I$ Tamburlaine," Explorations in Renaissance Culture 46, no. 2 (2020): 111-34.

${ }^{26}$ Tran, 112.

27 Tran, 122.

28 Tran, 115.

${ }^{29}$ Matthew Dimmock, "Tudor Turks: Ottomans Speaking English in Early Modern Sultansbriefe," English Literary Renaissance 50, no. 3 (2020): 335-58.

${ }^{30}$ Dimmock, 336.

${ }^{31}$ Dimmock 355.
} 
collective" and were perceived as a threat to European territories and ideologies. ${ }^{32}$ Marlowe, he argues, draws on these literary tropes to comment on contemporary fears of Muslim domination. Yet, because Marlowe positions Tamburlaine "on the edge of Saracen identity" and names him "the scourge of God," the title character threatens both Christian and Muslim communities and functions as a providential punisher of all who stand against him. Ultimately, while the plays narrate Tamburlaine's unification of an Islamic empire, they also showcase the reduction of Saracenic might. Indeed, the second play suggests that Tamburlaine's empire "is destined to crumble after his death, eliminating the newly unified Saracenic threat." 33

Sunil Macwan considered Marlowe's treatment of populism in the Tamburlaine plays, connecting the title character's political tactics to those of Elizabeth I and to the populist strategies used by current world leaders to deal with the coronavirus pandemic. ${ }^{34}$ Macwan reads Tamburlaine "as a critique of Queen Elizabeth's ingenious yet ruthless garnering of power through techniques of improvisation." ${ }^{35}$ Both rulers, he argues, projected a political persona by appropriating secular and religious symbols of power. While Elizabeth appropriated the Catholic symbolism of the Virgin Mary, Tamburlaine challenged Mahomet. Ultimately, according to Macwan, both monarchs fail to achieve improvisation as Tamburlaine cannot successfully change his son into his image and Elizabeth cannot fully take on the role of Virgin Mary as mother due to her childless state. In the end, Macwan calls on the current populist leaders of our world, advising them to embrace unified and collaborative approaches to government, rather than the populism he sees at work in Tamburlaine.

Marlowe's Tamburlaine not only engages with the consolidation of political power, but also, according to Lisa Wilde, highlights early modern scientific knowledge and its relation to England's imperial endeavours. ${ }^{36}$ Focusing on Tamburlaine's interest in cartographic details in 2 Tamburlaine, Wilde finds similarities between the title character's conquests and England's early colonial project, both of which involved empire building, exploration, cartography, and

\footnotetext{
32 Jeffrey McCambridge, "Inherited Insecurities and the Staging of Alterity: Islam in Marlowe's Tamburlaine," in New Directions in Early Modern English Drama: Edges, Spaces, Intersections, ed. Aidan Norrie and Mark Houlahan (Boston: De Gruyter, 2020), 138.

${ }^{33}$ McCambridge, 148.

${ }^{34}$ Sunil Macwan, "Populist Improvisation: A Reading of Marlowe's Tamburlaine the Great in the Context of the Coronavirus Pandemic," Renascence 72, no. 4 (2020): 195-213.

${ }^{35}$ Macwan, 196.

${ }^{36}$ Lisa Wilde, "Number and Narrative in Marlowe's Tamburlaine the Great," Studies in English Literature 15001900 60, no. 2 (Spring 2020): 229-55.
} 
mercantile finance. For Wilde, "the quantitative matter of empire, as worked out in the various practical mathematical arts — of navigation, military strategy, and accounting - that feature so conspicuously in Tamburlaine the Great, constitutes an important context for understanding not just the political and technical backdrop of the play, but also the imaginative trajectory at its center." ${ }^{37}$ Her investigation serves to historicize the play and reveal Marlowe's interest in and engagement with scientific issues of his day.

Emma Buckley's chapter in Conversations: Classical and Renaissance Intertextuality (ed. Syrithe Pugh) examines the connections between Tamburlaine and Caesar as evidenced by Marlowe's Lucans First Booke (1593/1600), his Tamburlaine plays, the anonymous drama The Tragedie of Caesar and Pompey, or Caesar's Revenge (1606), and Thomas May's Pharsalia (1627). ${ }^{38}$ In Lucans First Booke Marlowe, rather than simply translating the first book of Lucan's Pharsalia, imbued "the text with a different kind of energy by incorporating a cluster of selfquotation of his own previous work." 39 According to Buckley, Marlowe overlays his own Tamburlaine on top of Caesar, creating a hybrid Caesar that is not only more dynamic than Lucan's Caesar, but also breaks away from "the censorious moralising and committed fractures of Lucan's text." 40 The Tragedie of Caesar and Pompey and May's translation of Lucan, Buckley argues, utilize the Marlovian Caesar by framing Caesar's battles as acts of revenge and offering narratives containing repeated moments of chaotic bloodshed and an overreaching protagonist.

\section{Dido, Queen of Carthage}

In her monograph, Greeks and Trojans on the Early Modern Stage, Lisa Hopkins devotes two chapters to a study of Marlowe's portrayal of Aeneas in Dido and the influence of Marlowe's play on later literary representations of Aeneas. In her first chapter, "What's Actaeon to Aeneas?" Hopkins contends that Marlowe connects the Trojan Aeneas to the Greek Actaeon in order to critique Aeneas's status "as a model for the early modern colonial enterprise." 41 By presenting Aeneas as "a shabby figure" who often misunderstands his role as the founder of

\footnotetext{
${ }^{37}$ Wilde, 232.

${ }^{38}$ Emma Buckley, "Reviving Lucan: Marlowe, Tamburlaine, and Lucans First Booke," in Conversations: Classical and Renaissance Intertextuality, ed. Syrithe Pugh (Manchester: Manchester University Press, 2020), 91-120.

${ }^{39}$ Buckley, 96.

${ }^{40}$ Buckley, 102.

${ }^{41}$ Lisa Hopkins, Greeks and Trojans on the Early Modern Stage (Boston: De Gruyter, 2020), 15.
} 
Rome, Marlowe offers his audiences an Aeneas significantly different from Virgil's hero. ${ }^{42}$ Additionally, by yoking Aeneas to Actaeon, Marlowe suggests parallels between the two characters, both of whom are connected to tragic stag hunts, have problems with the same goddess, and are associated with cuckoldry. The connection between Aeneas and Actaeon, therefore, "serves to destabilize and undermine the idea of genealogical descent and by implication that of the translatio imperii." 43 In fact, Hopkins argues that Marlowe's works suggest that Tamburlaine instead of Aeneas was the probable heir to Rome and notes that "if the translatio imperii went anywhere it went to the east rather than to the west."44

Hopkins' second chapter explores how a number of early modern plays engage with the myth of Aeneas as the ur-colonizer by adopting or appropriating Marlowe's Dido and, in some instances, his Tamburlaine plays. The dramatic works Hopkins considers, which include texts by Thomas Heywood, George Peele, Dabridgcourt Belchier, and others, reveal how Marlowe's scepticism concerning the English colonial project influenced his fellow writers' interrogation of the same. Notably, Hopkins suggests that early modern English attempts to forge an empire jeopardized a stable national identity for colonizers and these writers sought to access a past English identity through "the act of recalling it, and recalling it particularly as it had been mediated through Marlowe in his repeated revisitings of the story of Aeneas."45

In addition to Lisa Hopkins's extended consideration of Dido, four articles and one book chapter offered critical readings of the play. Loren Cressler examines allusions to classical figures in works by Chaucer, Marlowe, and Shakespeare, arguing that early modern writers followed medieval understandings of these characters rather than depictions in classical texts. ${ }^{46}$ In stark contrast to Virgilian readings of Aeneas as a heroic leader of a displaced people, late medieval authors like Chaucer interpreted Aeneas as a traitor to the Trojans and Dido. Marlowe's Aeneas is based more closely on Chaucer's duplicitous Aeneas than Virgil's honourable hero, and Shakespeare, who, according to Ben Jonson, had "small Latin and less Greek," follows Marlowe's and Chaucer's understanding of Aeneas. Shakespeare's allusions to Aeneas in A Midsummer Night's Dream, according to Cressler, adapt "the dramatic shape of

\footnotetext{
42 Hopkins, 31.

${ }^{43}$ Hopkins, 39.

${ }^{44}$ Hopkins, 38.

45 Hopkins, 60.

${ }^{46}$ Loren Cressler, "Asinine Heroism and the Mediation of Empire in Chaucer, Marlowe, and Shakespeare," Modern Language Quarterly 81, no. 3 (September 2020): 319-47.
} 
Marlowe and Nashe's Dido to stage a male interloper's relationship with a besotted queen," thereby critiquing the dangers of imperialism by "divesting the hero of his capacity to do harm." 47 Allusions to Aeneas in A Midsummer Night's Dream, therefore, place Marlowe as the lens through which Shakespeare approached classical texts.

Heather Bailey analyses surrogate motherhood in Dido, arguing that Marlowe uses the figure of the disguised Cupid to explore social anxieties about surrogate parent-child relationships and the position of boy actors on the early modern stage. ${ }^{48}$ Both surrogate children and parents were at risk of exploitation and manipulation. Child actors, stepchildren, and wards were viewed as "mere commodities" and often exploited financially and sexually. ${ }^{49}$ As Bailey notes, though, "a surrogate child could be a threat to their adoptive parents" by threatening to disrupt the family unit. ${ }^{50}$ She sees this threat at work in Dido as the queen is manipulated by Cupid, who "embodies the power and potential threat of boy players." Viewed as both "an erotic plaything and substitute son," Marlowe's Cupid highlights the subversive position of boy actors, who undermined the political power of adults and threatened narrative structure. ${ }^{51}$

Responding to Ruth Lunney's call for further engagement with "identity, memory, and place" in Dido, two scholars considered Marlowe's treatment of Carthage in the play. ${ }^{52}$ Nandini Das asserts that Carthage, like Rome, was used by early modern writers to investigate the colonial activities of European nations. Focusing "on the strange tricks that the city of Carthage plays with both time and space," Das examines three late sixteenth century texts: Garcilaso de la Vega's "Sonnet to Boscán from Goleta," Bruegel the Elder's "Great Tower of Babel," and Marlowe's Dido Queen of Carthage. 53 These authors engaged with Carthage to "both envision and interrogate" contemporary imperial aspirations. ${ }^{54}$ Marlowe, she argues, uses Carthage "as a complex memorial place," which is revealed through "the indigenous African presence of

\footnotetext{
${ }^{47}$ Cressler, 321, 323.

${ }^{48}$ Heather Bailey, “'Thou Shalt be Dido’s Son': Surrogate Motherhood in Christopher Marlowe's Dido, Queen of Carthage," Journal for Early Modern Cultural Studies 20 (2020): 83-109.

49 Bailey, 98.

50 Bailey, 102.

51 Bailey, 106.

52 Ruth Lunney, “Dido, Queen of Carthage," in Christopher Marlowe at 450, ed. Sara Munson Deats and Robert A. Logan (Farnham: Ashgate, 2015), 42.

${ }^{53}$ Nandini Das, "Time and Memory in Carthage," Renaissance Studies 35, no. 3 (2021): 360-85. Originally published online in 2020.

54 Das, 361.
} 
Iarbus" and Aeneas's attempts to rebuild Carthage as Troy. ${ }^{55}$ Indeed, while celebrating Aeneas's goals of creating a new Troy, Marlowe's work also points to the inevitable destruction of a land and people - a historical reality always present in imperial ambitions.

Andrew Bozio also considers place in Dido and Tamburlaine, challenging earlier scholarly assertions that Marlowe's works lacked a connection to place. In his analysis of Dido, Bozio contends that "ecological memory [...] provides the foundation of the play's translatio imperii" by revealing the "tension between a form of recollection that sees the past in place and another that views place as the scaffolding for imperial ambition." ${ }^{2}$ Aeneas's engagement with Carthage establishes this paradox as he initially reimagines the city as Troy, but when faced with the truth of Troy's destruction, decides to transform Carthage into a new empire that will take the place of his ruined city. Bozio reads Aeneas's reactions to Troy and Carthage as evidence of an affective struggle, which shows "the ease with which memory can erode the particularity of a site in using that place to remember another." 57 The Tamburlaine plays also engage with ecological issues, which is demonstrated by the title character's "model of thought," which combines earthly territorial thinking with ambitions to move beyond the earthly realm. Bozio suggests that "Tamburlaine imagines a reciprocal relationship between thought and the cosmos, wherein human ambition reshapes the contours of the world." ${ }^{58}$ In contrast to Tamburlaine, Zenocrate demonstrates ecological memory through her mourning of the ruin of Damascus, a melancholy reaction to loss of place. Tamburlaine likewise uses ecological memory to mourn Zenocrate, but his method becomes a repetitive process as he "remembers and avenges Zenocrate's death through the wrathful destruction of all the places he subsequently encounters." 59

\section{Edward II}

Kit Heyam's case study of Edward II's reputation in medieval and early modern England (The Reputation of Edward II, 1305-1697) not only provides insights on historical shifts in our understanding of sexual vocabularies, but also offers a convincing analysis of the importance of

\footnotetext{
55 Das, 382-83.

${ }^{56}$ Andrew Bozio, "Marlowe and the Ecology of Remembrance," in Thinking Through Place on the Early Modern English Stage (Oxford: Oxford University Press, 2020), 68.

${ }^{57}$ Bozio, 80.

${ }^{58}$ Bozio, 86.

${ }^{59}$ Bozio, 94.
} 
Marlowe's play in the development of historical narratives.$^{60}$ What the general populace in England remembered during this period and what we today think of when we encounter the illstarred king, as Heyam notes, is partial, representing "the preoccupations of modern scholars and premodern commentators alike." ${ }^{91}$ In short, the narratives of Edward's reign focused on his intimate relationships with his favourites, their influence over political events, and his horrific murder with a red-hot poker. Heyam reveals that originally many of the terms medieval and early modern writers used to describe Edward's sexuality (minion, riot, and sodomite) contained dual meanings, allowing for "suggestions of sexual transgression with plausible deniability." 62 Marlowe's play, however, solidified Edward's reputation as a man who engaged in sexual relations with his male favourites by making explicit the homoerotic intimacy between the king and Gaveston. Following the staging and publication of Edward II, other writers followed suit by presenting the relationships of Edward and his favourites as unmistakably sexual. Additionally, "the way in which writers depicted Edward's emotional attachment to his favourites shifted over time," initially portraying Gaveston as Edward's "sworn brother" but later depicting their relationships as romantic and sympathetic as shown in Edward II. ${ }^{63}$

Intensified interest in Edward's story during the Elizabethan and Jacobean periods can also be linked to Marlowe's play, as not only did the narrative deal with civil instability, but also with "favourites with excessive political power and intimate access to the monarch," which was a significant contemporary concern. ${ }^{64}$ In the end, Heyam found that the seventeenth century reputation of Edward II, which included not only his negligence as a reigning monarch and attachment to male favourites, but also his "sympathetic, suffering humanity as a deposed King" was cemented by Marlowe. ${ }^{65}$ Yet Marlowe did not simply use historical source material to compose an enjoyable play; instead, Heyam argues that Marlowe's Edward II "initiated a significant historiographical shift" and influenced the retelling of the king's life across a range of genres, both those purporting to be factual and those clearly meant as literary. ${ }^{66}$ Understanding the value of Marlowe's play as a historical narrative that influenced the composition and

\footnotetext{
${ }^{60}$ Kit Heyam, The Reputation of Edward II, 1305-1697: A Literary Transformation of History (Amsterdam: Amsterdam University Press, 2020).

${ }^{61}$ Heyam, 13.

${ }^{62}$ Heyam, 60.

${ }^{63}$ Heyam, 101.

${ }^{64}$ Heyam, 207.

${ }^{65}$ Heyam, 275.

${ }^{66}$ Heyam, 279.
} 
understanding of history, Heyam suggests, should prompt scholars to rethink how we engage with early modern literary works. "Marlowe," Heyam reminds us, "was not the end-point of a process whereby a mass of facts was moulded into a finished literary product: his play went on to influence chronicles in its own right."

\section{Doctor Faustus}

Although much attention is usually given to Doctor Faustus, the play attracted less critical interest in 2020. Mark James Richard Scott argued that rather than reading the play as posing questions about Faustus' damnation, Marlowe provided his audience and readers with "an incomparable portrait of the experience of reprobate living." ${ }^{68}$ Engaging with the religious trauma experienced by early modern English people in the wake of the Reformations, Marlowe depicts Faustus as part of a Calvinist universe in which he is always reprobate and has no chance of redemption. Scott cites the moments in the play when Faustus reveals his inability to read or interpret biblical passages as proof of the doctor's reprobation; this reprobation, Scott suggests, would have resonated with audience members, who likewise experienced difficulties understanding reformed theology, in particular Calvinism. By exposing the trauma of Calvinism, then, Marlowe's play allowed its audience and readers a chance to work through their own religious trauma collectively.

In her exploration of Doctor Faustus, Katherine Walker observes that the clowns and clownish characters in the play "have much to teach us about the perverted means through which ones learns from the devil." ${ }^{\prime 99}$ Although these figures obtain access to demonic knowledge, Walker suggests that such understanding "is always an illusion, akin to the theater itself" because the demons bestow knowledge that is located in the material rather than spiritual world. ${ }^{70}$ Ultimately, not only the clowns, but also Faustus, never gain understanding of the immaterial or spiritual dominions, implying that Satan's knowledge, in contrast to contemporary demonological literature's claims, was limited to the earthly realm.

\footnotetext{
${ }^{67}$ Heyam, 283.

${ }^{68}$ Mark James Richard Scott, “'That's hard': Christopher Marlowe's Doctor Faustus and the Trauma of Reprobation," Early Theatre 23, no. 2 (2020): 9.

${ }^{69}$ Katherine Walker, “Clowns and Demonic Learning in Doctor Faustus,” ELH 87, no. 2 (2020): 406.

${ }^{70}$ Walker, 406.
} 
Laura Seymour examines the performances of banquets on the early modern stage, noting that demons often appear when characters mis-say or fail to say grace. Seymour finds that a number of plays indicate that in the early modern theological worldview a failure to say grace had spiritual repercussions. Marlowe's play reflects a "belief that eating without saying grace leaves one open to the malice of prowling devils."71 Faustus's and Mephistopheles's comedic interruption of the Pope's banquet, Seymour argues, occurs because the Pope fails to say grace before eating. While this farcical incident highlights Faustus's unwise use of demonic power for pranks rather than for obtaining knowledge, Seymour reads the scene as also making "visible contemporary moral anxieties about eating." 72

In a particularly well-written piece, Dustin W. Dixon and John S. Garrison explore the representations of Helen of Troy in Euripides's and Marlowe's plays. In both dramatic works, the authors "use Helen's incredible beauty as a focal point for exploring theatre's power to render the impossible possible." ${ }^{\prime 73}$ For mimesis to work on the stage, the audience has to have an imaginative investment in what is technically impossible. While Euripides's play challenges Homer's narrative by offering an alternate mythological tradition that demonstrates Helen's protean nature, Marlowe's inclusion of Helen in Doctor Faustus more fully engages with questions of imitation and suspension of disbelief. The Helen presented to Faustus is questionable — she might be a demon, or she might be the real Helen. Faustus, and by extension the viewers, express doubt, but are prepared to accept her as the beautiful woman of legend, which, according to Dixon and Garrison, speaks "to the desire of an audience member to be transported" when witnessing a spectacle. ${ }^{74}$ Indeed, for Euripides and Marlowe, the use of mimesis allows actors to "hold an inscrutable power over spectators akin to witnessing the supernatural." 75

\footnotetext{
${ }^{71}$ Laura Seymour, "The Feasting Table as the Gateway to Hell on the Early Modern Stage and Page," Renaissance Studies 34, no. 3 (2020): 394.

${ }^{72}$ Seymour, 395.

${ }^{73}$ Dustin W. Dixon and John S. Garrison, "The spectacle of Helen in Euripides' Helen and Marlowe's Doctor Faustus," Classical Receptions Journal 13, no. 2 (2021): 159. Originally published online in 2020.

${ }^{74}$ Dixon and Garrison, 172.

${ }^{75}$ Dixon and Garrison, 160.
} 


\section{The Jew of Malta}

The Jew of Malta attracted considerable critical attention in 2020, surpassed only by scholarship devoted to the Tamburlaine plays. In a chapter for Ovid and Masculinity in English Renaissance Literature, Lisa Starks explores the depiction of Barabas, arguing that Marlowe "fuses the image of Ovid's Proteus with that of the Stage-Jew" in order to expose contemporary anti-Semitic stereotypes and reveal connections between gender fluidity and the theatre. ${ }^{76}$ Providing a detailed definition and history of the Stage-Jew, Starks reads this figure as embodying a unique position on the early modern stage because it combined stereotypes of "the Jew-Devil, the medieval Vice, and the Machiavel." 77 Marlowe, rather than upholding these typical portrayals, satirizes the stereotype while simultaneously associating Barabas with Proteus by stressing the title character's ability to transform himself and act as playwright within the world of the play itself. Marlowe's portrayal of Barabas ultimately, then, functions as "a scathing critique of heroic masculinity, Petrarchan love, and normative sexuality."78

Jaecheol Kim, in his essay on The Jew of Malta, analyses how Marlowe uses city walls within the play. ${ }^{79}$ Viewing the walls of Malta "as a rhetorical entity," Kim argues that these structures reveal how the community preserved its values and determined its level of tolerance for outsiders. ${ }^{80}$ The walls policed the borders of Malta, excluding religious and ethnic others as well as individuals deemed dangerous to the body politic such as pimps and courtesans. Using contemporary medical discourse that defined the community as a living organism and outsiders as contagions, Kim contends that Marlowe positions Barabas as "a sort of excrement or miasma that the city should properly release through the sewer drains for its health." 81 Thus, in Kim's reading of the play, Barabas functions as a deadly invasive organism introduced inside the city walls in order to rid Malta of the "alien pathogens" - the Turks and Catholics. ${ }^{82}$

Cody Krumrie's study of the removal or adoption of religious clothing in early modern plays analysed The Jew of Malta alongside Lewis Wager's The Life and Repentaunce of Mary

\footnotetext{
${ }^{76}$ Lisa S. Starks, "Ovid's Proteus and the Figure of the Male Jew in Marlowe's The Jew of Malta," in Ovid and Masculinity in English Renaissance Literature, ed. John S. Garrison and Goran Stanivukovic (Chicago: McGillQueen's University Press, 2020), 267-68.

${ }_{77}^{77}$ Starks, 273.

${ }^{78}$ Starks, 268.

${ }^{79}$ Jaecheol Kim, "Marlowe's Sacred City and the Walls in The Jew of Malta," Cahiers Élisabéthains 101, no. 1 (April 2020): 26-44.

${ }^{80} \mathrm{Kim}, 28$.

${ }^{81} \mathrm{Kim}, 34$.

${ }^{82} \mathrm{Kim}, 40$.
} 
Magdalene and Robert Greene's Friar Bacon and Friar Bungay. According to Krumrie, ecclesiastical garments served both to hide and reveal individuals, which made them ideal as theatrical costumes following the Reformations. On the stage, religious clothing became a type of theatrical language, not only signifying religious affiliation or conversion, but also allowing characters to counterfeit conversion. Abigail's portrayal highlights the range of ways nuns' clothing could be used on stage as she moves from Jewish girl to pretend Catholic nun and finally to true convert. Late sixteenth-century understandings "of clothing as indicators of one's inward self," Krumrie suggests, made theatrical performances of faith believable while simultaneously revealing "tensions surrounding religious conversion as an act that is both performable and, in some cases, reversible." 83

As part of a broader study of how literature engaged with convents and novices in the wake of the English Reformations, Vanessa Rapatz also concentrated on the character of Abigail in The Jew of Malta ${ }^{84}$ Reading Abigail as the embodiment of the architectural turn used in cloistered convents that allowed for nuns to receive gifts from those outside but protected them from intrusion, Rapatz explores the character's liminal position as a woman moving between active and passive roles. Although Abigail's first conversion is feigned and at the behest of her father, her return to the convent, Rapatz argues, is an act of resistance. Within the play the use of the word "turn" and the suggestion of the material structure, "the turn," connotate, for Rapatz, religious conversion as well as shifting sexual and ethnic identities. Accordingly, "Abigail herself embodies the movement of the turn, as she rotates between allegiances and navigates her complex identities through the narrative." 85

\section{Hero and Leander}

Marlowe's Hero and Leander drew critical attention from one scholar. Examining Marlowe's influence on dramatic satire, Sarah K. Scott argues that Lording Barry, the playwright and manager of the Children of the King's Revels, drew inspiration from the epyllion and alluded to

\footnotetext{
${ }^{83}$ Cody W. Krumrie, "Physical and Spiritual Conversion: Femininity and Religious Materiality in Three Early Modern English Plays," Comitatus: A Journal of Medieval and Renaissance Studies 51 (2020): 183, 158.

${ }^{84}$ Vanessa L. Rapatz, “'Turn'd to a Nunnery': Abigail's Agency in The Jew of Malta,” In Convents and Novices in Early Modern English Dramatic Works: In Medias Res (Kalamazoo: Medieval Institute Publications, 2020), $25-48$. ${ }^{85}$ Rapatz, 35.
} 
it in his London comedy, The Family of Love (1608). ${ }^{86}$ Scott explores two Ovidian traditions at work in both Marlowe's poem and Barry's play: “One is that of a romantic Ovid, and the other is the cynical, satirical expression of the libertine." 87 By alluding to Hero and Leander in his comedy, Barry aims not only to mock romantic love, but also to connect himself to the Marlovian literary tradition and critique Ovidian cynicism. ${ }^{88}$ In short, Barry ridicules the ideal of romantic love and then rehabilitates it through his use of Marlowe's poem. For Scott, Barry's engagement with Hero and Leander reveals that "Marlowe's influence in the development of city comedy is more pronounced and varied than we might think." 89

\section{Computational Stylometry and Authorship Attribution}

Inspired in part by the editors of The New Oxford Shakespeare's 2016 decision to list Marlowe as co-author of Shakespeare's Henry VI, Parts I, II, and III, many scholars examined Marlowe's works using computer-aided analyses of wording and linguistic patterns, asking if algorithms can settle questions of authorship and canon formation. ${ }^{90}$ Current work in stylometry, though, as a number of critics noted, does not always provide clear answers to such questions, which led some scholars to reassess authorship attributions using not only computational stylistics but also looking closely at theatre history, stage directions, and poetic style.

Although the New Oxford Shakespeare now attributes parts of all three Henry VI plays to Shakespeare, Marlowe, Thomas Nashe, and an anonymous author, a number of scholars cast doubt on these claims. Warren Chernaik, in his examination of assertions that Marlowe penned significant portions of Henry VI, argues that numerous issues make such claims questionable, including "the instability of texts; statistical methods and their problems; the ownership of plays during this period; and the use of parallel passages to determine ownership." 91 For Chernaik, similarities between lines in early Shakespeare plays and those of Marlowe reveal not that the two collaborated on these works, but instead provide evidence that appreciation for Marlowe's

\footnotetext{
${ }^{86}$ Sarah K. Scott, "Modern for the Time: Lording Barry, Christopher Marlowe, and Ovid," Studies in English Literature 1500-1900 60, no. 2 (Spring 2020): 347-64.

${ }^{87} \mathrm{Scott}, 350$.

${ }^{88} \mathrm{Scott}, 352,358$.

${ }^{89}$ Scott, 348.

${ }^{90}$ Gary Taylor, John Jowett, Terri Bourus, and Gabriel Egan, eds., The New Oxford Shakespeare: The Complete Works (Oxford: Oxford University Press, 2016).

${ }^{91}$ Warren Chernaik, "Theatrical Companies and Their Plays: Shakespeare and Marlowe," Medieval \& Renaissance Drama in England 33 (2020): 171.
} 
plays was widespread and that many contemporary playwrights sought to imitate Marlowe's writings. ${ }^{92}$ Pervez Rizvi also critiques the method used to assign parts of Henry VI to Marlowe. The method, called function word adjacency networks (WANs), looks at parts of speech that do not carry lexical meaning but instead create grammatical relationships between words with clear meaning. ${ }^{93}$ Distinguishing individual authors, then, relies on "the function words found in a text, the order in which they occur, and how far apart they occur."94 Rizvi argues that the method is intrinsically flawed because it does not differentiate between the proximity of paired function words and those running the tests misleadingly compared shorter texts with longer texts. Overall, Rizvi finds "that the function word adjacency network method suffers from defects that should cause us to doubt its efficacy," thereby casting doubt on the recent authorship attribution. ${ }^{95}$

Ros Barber expresses similar doubts in her study of the Zeta test. This test, which essentially determines authorship based on "lexical words" used more or less frequently by one author than another, was employed by John Burrows and Hugh Craig to identify authorial styles in the three Henry VI plays and led to their assertion that Marlowe was responsible for significant portions of the plays. ${ }^{96}$ Barber argues that the small data sets examined using Zeta tests are unreliable, which includes all of Craig's tests on the first two Henry VI plays. After running similar tests, she found that stylistic differences between Marlowe and Shakespeare were "too close for Zeta to call."97

The authorship of the 1594 Quarto text of Dido, Queen of Carthage also remains a matter of debate, which was taken up by Darren Freebury-Jones and Marcus Dahl. The authors surveyed "scholarship on the prosody, vocabulary, phraseology, and use of rhyme" in Dido, to determine whether Thomas Nashe either co-wrote the play with Marlowe or added to it. After a thorough analysis, Freebury-Jones and Dahl found more connections within the play to other accepted Marlovian works than to Nashe's writing, and concluded that 'there seems 'good

\footnotetext{
${ }^{92}$ Chernaik, 174.

${ }^{93}$ Pervez Rizvi, "Authorship Attribution for Early Modern Plays Using Function Word Adjacency Networks: A Critical View," ANQ: A Quarterly Journal of Short Article, Notes and Reviews 33, no. 4 (2020): 328-31.

${ }^{94}$ Rizvi, 329.

${ }^{95}$ Rizvi, 331.

96 John Burrows and Hugh Craig, "The Joker in the Pack? Marlowe, Kyd, and the Co-Authorship of Henry VI, Part 3," in The New Oxford Shakespeare Authorship Companion, ed. Gary Taylor and Gabriel Egan (Oxford: Oxford University Press, 2017), 194-217.

${ }^{97}$ Ros Barber, "Big Data or Not Enough? Zeta Test Reliability and the Attribution of Henry VI," Digital Scholarship in the Humanities 36, no. 3 (2021): 561. Originally published online in 2020.
} 
reason' for discounting the notion that Dido is a direct collaboration between Nashe and Marlowe." 98

Hartmut Ilsemann also revisited Marlowe's canonical plays using a stylometric tool called Rolling Delta, which is based on the writers' use of high frequency function words, which Ilsemann believes show the characteristics of a playwright's individual style. In stark contrast to most early modern scholars, Ilsemann argues that Marlowe's authorship of the Tamburlaine plays is questionable, noting that the author of the text "emerges as stylistically also dominant in the anonymous play The Tragedy of Locrine," as well as in a Thomas Kyd play and two George Peele plays. ${ }^{99}$ According to Ilsemann, the plays typically attributed to Marlowe are "stylistically highly diverse," and Tamburlaine, in particular, shows few similarities with other works written by Marlowe. Ilsemann, who is notorious for questioning Marlowe's position as a major early modern playwright, concludes that "the canonization of the plays occurred only in the nineteenth century, and the Marlowe we have inherited - the poet, spy, atheist, homosexual, and so on - is almost entirely an invention of the twentieth century." 100

The difficulties of determining co-authorship and establishing the canons of both Marlowe and Shakespeare concern Rory Loughnane as well. In his award-winning contribution to The Birth and Death of the Author: A Multi-Authored History of Authorship in Print (edited by Andrew J. Power), Loughnane offers a chronological summary of the publications and stagings of Shakespeare's 2 and 3 Henry VI: The First Part of the Contention and The True Tragedy of Richard Duke of York, assessing the plays prior to the printing of the First Folio in 1623. ${ }^{101}$ Although Loughnane's main focus is finding traces of Shakespeare's authorship in these plays, he also turns to Marlowe, noting that “there are no known allusions in either Marlowe's own work or that of others that connect him to the Henry VI plays." Additionally, despite Marlowe's notoriety and the publication of three of his plays in 1594 with Marlowe's name “prominently displayed on each title page," Thomas Millington's early printed versions of Henry

\footnotetext{
${ }^{98}$ Darren Freebury-Jones and Marcus Dahl, "Searching for Thomas Nashe in Dido, Queen of Carthage," Digital Scholarship in the Humanities 35, no. 2 (2020): 304.

${ }^{99}$ Hartmut Ilsemann, “The Marlowe Corpus Revisited," Digital Scholarship in the Humanities 36. no. 2 (2021): 333. Originally published online in 2020 .

${ }^{100}$ Ilsemann, 333.

${ }^{101}$ Rory Loughnane, "Sixteenth Century: Shakespeare, Marlowe, and Traces of Authorship," in The Birth and Death of the Author: A Multi-Authored History of Authorship in Print, ed. Andrew J. Power (New York: Routledge, 2020), 54-74. Loughnane was awarded the 2019 Calvin and Rose G. Hoffman Prize for distinguished scholarly work on Christopher Marlowe for this piece.
} 
VI include no mention of Marlowe. ${ }^{102}$ Shakespeare's name does not appear on the title page either. Reasons for leaving out their names, according to Loughnane, may include that the plays were not yet associated with a particular playwright, but more importantly, reveal the complex ways that early modern dramatic texts were authored, staged, revised, published, and remembered.

Roslyn L. Knutson also visited the question of Marlowe's collaboration with contemporary playwrights, combining "claims of computational stylistics" with scholarship about "the theatrical marketplace in Marlowe's time" in order to gain a broader understanding of his place in the Elizabethan theatrical world. ${ }^{103}$ While scholars traditionally viewed Marlowe as "an unruly and iconoclastic figure" who preferred to work alone, Knutson questions this assumption. ${ }^{104}$ Marlowe's work with a number of different theatrical companies suggests that he more likely collaborated with other playwrights, including Shakespeare, which validifies the findings of computational programs in attributing portions of Shakespeare's plays to Marlowe. Marlowe's likely partnerships with others, though, doesn't align with the accepted theatrical and biographical history of Marlowe as a lone and transgressive playwright and threatens accepted views of Shakespeare as the most gifted early modern dramatist. For Knutson, though, "recent arguments of authorship attribution put Marlowe in a story where he is more like his fellows, as flexible as they in writing solo or in teams." 105

\section{Bibliography}

Bailey, Heather. “'Thou Shalt be Dido's Son': Surrogate Motherhood in Christopher Marlowe's Dido, Queen of Carthage.” Journal for Early Modern Cultural Studies 20 (2020): 83109.

Barber, Ros. "Big Data or Not Enough? Zeta Test Reliability and the Attribution of Henry VI." Digital Scholarship in the Humanities 36, no. 3 (2021): 542-64.

Baricz, Carla. "Richard Jones's Tamburlaine the Great, or How to Print an Early Modern Play and Sequel." Sixteenth Century Journal 51, no. 1 (2020): 29-53.

\footnotetext{
${ }^{102}$ Loughnane, 70, 71.

103 Roslyn L. Knutson, “Christopher Marlowe and a Mashup of Stylometry and Theater History," Memoria di Shakespeare: A Journal of Shakespeare Studies 7 (2020): 140.

${ }^{104}$ Knutson, 139.

105 Knutson, 157.
} 
Bourne, Claire M. L. Typographies of Performance in Early Modern England. Oxford: Oxford University Press, 2020.

Bozio, Andrew. "Marlowe and the Ecology of Remembrance." In Thinking Through Place on the Early Modern English Stage, 65-97. Oxford: Oxford University Press, 2020.

Buckle, Emma. "Reviving Lucan: Marlowe, Tamburlaine, and Lucans First Booke." In Conversations: Classical and Renaissance Intertextuality, edited by Syrithe Pugh, 91120. Manchester: Manchester University Press, 2020.

Burrows, John and Hugh Craig. "The Joker in the Pack? Marlowe, Kyd, and the Co-Authorship of Henry VI, Part 3." In The New Oxford Shakespeare Authorship Companion, edited by Gary Taylor and Gabriel Egan, 194-217. Oxford: Oxford University Press, 2017.

Chernaik, Warren. "Theatrical Companies and Their Plays: Shakespeare and Marlowe.” Medieval \& Renaissance Drama in England 33 (2020): 167-87.

Cressler, Loren. "Asinine Heroism and the Mediation of Empire in Chaucer, Marlowe, and Shakespeare." Modern Language Quarterly 81, no. 3 (September 2020): 319-47.

Das, Nandini. “Time and Memory in Carthage." Renaissance Studies 35, no. 3 (2021): 360-85.

Dimmock, Matthew. "Tudor Turks: Ottomans Speaking English in Early Modern Sultansbriefe." English Literary Renaissance 50, no. 3 (2020): 335-58.

Dixon, Dustin W. and John S. Garrison. "The Spectacle of Helen in Euripides' Helen and Marlowe's Doctor Faustus.” Classical Receptions Journal 13, no. 2 (April 2021): 15977.

Freebury-Jones, Darren, and Marcus Dahl. "Searching for Thomas Nashe in Dido, Queen of Carthage." Digital Scholarship in the Humanities 35, no. 2 (June 2020): 296-306.

Heyam, Kit. The Reputation of Edward II, 1305-1697. Amsterdam: Amsterdam University Press, 2020.

Hopkins, Lisa. Greeks and Trojans on the Early Modern Stage. Boston: De Gruyter, 2020.

Hunt, Maurice. "Friendship in Marlowe's Tamburlaine the Great." Medieval and Renaissance Drama in England 33 (2020): 118-43.

Ilsemann, Hartmut. “The Marlowe Corpus Revisited.” Digital Scholarship in the Humanities 36, no. 2 (2021): 333-60.

Kim, Jaecheol. "Marlowe's Sacred City and the Walls in The Jew of Malta." Cahiers Élisabéthains 101, no. 1 (April 2020): 26-44. 
Knutson, Roslyn L. "Christopher Marlowe and a Mashup of Stylometry and Theater History." Memoria di Shakespeare: A Journal of Shakespeare Studies 7 (2020): 138-162.

Krumrie, Cody W. "Physical and Spiritual Conversion: Femininity and Religious Materiality in Three Early Modern English Plays.” Comitatus: A Journal of Medieval and Renaissance Studies 51 (2020): 157-85.

Loughnane, Rory. "Shakespeare, Marlowe, and Traces of Authorship." In The Birth and Death of the Author: A Multi-Authored History of Authorship in Print, edited by Andrew J. Power, 54-78. New York: Routledge, 2020.

Lunney, Ruth. “Dido, Queen of Carthage.” In Christopher Marlowe at 450, edited by Sara Munson Deats and Robert A. Logan, 13-50. Farnham: Ashgate, 2015.

McCambridge, Jeffrey. "Inherited Insecurities and the Staging of Alterity: Islam in Marlowe's Tamburlaine.” In New Directions in Early Modern English Drama: Edges, Spaces, Intersections, edited by Aidan Norrie and Mark Houlahan, 135-49. Boston: De Gruyter, 2020.

McInnis, David, ed. Tamburlaine: A Critical Reader. London: Bloomsbury, 2020.

McKeen, Christopher. "Christopher Marlowe, Literary History, and the Lyrical Style of Blank Verse.” English Literary Renaissance 50, no. 2 (2020): 173-203.

Macwan, Sunil. "Populist Improvisation: A Reading of Marlowe's Tamburlaine the Great in the Context of the Coronavirus Pandemic.” Renascence 72, no. 4 (2020): 195-213.

Rapatz, Vanessa L. “'Turn'd to a Nunnery': Abigail's Agency in The Jew of Malta.” In Convents and Novices in Early Modern English Dramatic Works: In Medias Res, 25-48. Kalamazoo: Medieval Institute Publications, 2020.

Rizvi, Pervez. "Authorship Attribution for Early Modern Plays Using Function Word Adjacency Networks: A Critical View." ANQ: A Quarterly Journal of Short Articles, Notes and Reviews 33, no. 4 (2020): 328-31.

Scott, Mark James Richard. "“That's hard': Christopher Marlowe's Doctor Faustus and the Trauma of Reprobation." Early Theatre 23, no. 2 (2020): 9-30.

Scott, Sarah K. "Modern for the Time: Lording Barry, Christopher Marlowe, and Ovid." Studies in English Literature 1500-1900 60, no. 2 (Spring 2020): 347-64.

Seymour, Laura. "The Feasting Table as the Gateway to Hell on the Early Modern Stage and Page.” Renaissance Studies 34, no. 3 (2020): 392-411. 
Starks, Lisa S. "Ovid's Proteus and the Figure of the Male Jew in Marlowe's The Jew of Malta." In Ovid and Masculinity in English Renaissance Literature, edited by John S. Garrison and Goran Stanivukovic, 267-85. Chicago: McGill-Queen's University Press, 2020.

Taylor, Gary, John Jowett, Terri Bourus, and Gabriel Egan, eds. The New Oxford Shakespeare: The Complete Works. Oxford: Oxford University Press, 2016.

Tran, Jeanette Nguyen “'Or Else Were this a Savage Spectacle': the Narrative Possibilities of Spectacle in I Tamburlaine.” Explorations in Renaissance Culture 46, no. 2 (2020): 11134.

Walker, Katherine. "Clowns and Demonic Learning in Doctor Faustus.” ELH 87, no. 2 (2020): 405-31.

Wilde, Lisa. "Number and Narrative in Marlowe's Tamburlaine the Great." Studies in English Literature 1500-1900 60, no. 2 (2020): 229-55. 